УДК 336.7

\title{
АНАЛІЗ ФАКТОРІВ, ЯКІ ВПЛИВАЮТЬ НА ЕФЕКТИВНІСТЬ ФУНКЦІОНУВАННЯ ЛІЗИНГОВИХ КОМПАНІЙ УКРАЇНИ
}

\section{ANALYSIS OF FACTORS AFFECTING THE EFFICIENCY OF UKRAINIAN LEASING COMPANIES}

\author{
Мігулка Ольга Олексіївна \\ аспірант, \\ Дрогобицький державний педагогічний університет імені Івана Франка \\ ORCID: https://orcid.org/0000-0001-9688-2009 \\ Migulka Olga \\ Drohobych Ivan Franko State Pedagogical University
}

\begin{abstract}
У статті побудовано низку економетричних моделей оцінювання ефективності функціонування українських лізингових компаній за 2019-2020 роки, у яких пояснювальними змінними було взято собівартість реалізованої продукції, чистий прибуток, основні засоби, адміністративні витрати та інші витрати. У ролі пояснюваних змінних було використано середні значення показників ефективності, отриманих з допомогою DEA аналізу. Було показано, що у випадку CRS та VRS моделей, зростання собівартості реалізованої продукції негативно впливає на ефективність функціонування лізингових компаній. Аналіз показав, що чим більший чистий прибуток, тим ближче лізингові компанії працюють до оптимального для них масштабу діяльності, який визначається обсягом довгострокової дебіторської заборгованості лізингодавця та розміром його активів.

Ключові слова: лізингові компанії, ефективність лізингу, DEA аналіз, CRS ефективність, VRS ефективність, есрективність масштабу.
\end{abstract}

В статье построен ряд эконометрических моделей оценки эффективности функционирования украинских лизинговых компаний за 2019-2020 годы, в которых объяснительными переменными была взята себестоимость реализованной продукции, чистая прибыль, основные средства, административные расходы и другие расходы. В качестве объясняемых переменных были использованы средние значения характеристик эффрективности, полученных с помощью DEA анализа. Было показано, что в случае CRS и VRS моделей рост себестоимости реализованной продукции негативно влияет на эффрективность фрункционирования лизинговых компаний. Анализ показал, что чем больше чистая прибыль, тем ближе лизинговые компании работают к оптимальному для них масштабу деятельности, определяемому объемом долгосрочной дебиторской задолженности лизингодателя и размером его активов.

Ключевые слова: лизинговые компании, эфффективность лизинга, DEA анализ, CRS эфффективность, VRS эффрективность, эфффективность масштаба.

In the article a number of econometric models for evaluating the performance of Ukrainian leasing companies for 2019-2020, in which the cost of sales, net profit, fixed assets, administrative expenses and other expenses were taken as explanatory variables were built. The regression models obtained in the work make it possible to determine the sets of both external and internal factors that have the most significant impact on the performance of leasing companies. The average values of the performance characteristics obtained using the Data Envelopment Analysis (DEA) approach were used as the explained variables. It was shown that in the case of Constant Returns to Scale (CRS) and Variable Returns to Scale (VRS) models, the increase in the cost of sales has a negative impact on the efficiency of the functioning of leasing companies. Efficiency based on the VRS assumption or BCC model, which takes into account the change in efficiency with changes in the scale of operations, is most sensitive to changes in administrative costs, the size of fixed assets and cost of goods sold. Efficiency based on the CRS assumption or the CCR model, which provides for a proportional increase in the input and initial performance indicators of companies, turned out to be the most sensitive to changes in net profit and cost of sales. The analysis showed that such variables as total assets, receivables, net income from sales of products, other operating income, current liquidity ratio turned out to be statistically insignificant for the constructed regression models for assessing the values of the new performance indicators proposed by the authors of leasing companies in Ukraine, obtained as average values of the corresponding performance of each company. Thus, most often in regression models for evaluating the effectiveness of the functioning of leasing companies, the cost of sales and 
profit act as explanatory variables. In other words, according to the constructed regression models, the efficiency of the lessor's activity in most cases depends on the value of the property transferred to them for financial lease and the net profit of such companies.

Keywords: leasing companies, leasing efficiency, DEA analysis, CRS efficiency, VRS efficiency, Scale efficiency.

Постановка проблеми. Важливим етапом якісного аналізу особливостей фрункціонування лізингового бізнесу у бідь-якій країні є ідентиорікація чинників, які спричиняють статистично значущий вплив на продуктивність та ефрективність роботи основних учасників цього ринку лізингових компаній. Крім падіння попиту на лізингові послуги, яке обумовлене зниженням ділової активності протягом останніх двох років через карантинні обмеження, сьогодні для ринку лізингових послуг характерним $€$ наявність значних системних кредитних ризиків, що стримують можливості ефективного фрункціонування сектора. Ці ризики означають зростання ймовірності підвищення найближчим часом рівня проблемної заборгованості за лізинговими угодами, що може спричинити значний тиск на капіталізацію цього сектору. Через це більшість лідируючих лізингових компаній як у сегменті великого бізнесу, так і в сегменті роздрібного лізингу прогнозуючи таку тенденцію, не прагнуть нарощувати порторель у поточних умовах. Усе це обумовлює необхідність проведення аналізу чинників, які у сучасних умовах спричиняють найбільш суттєвий вплив на ефрективність фрункціонування лізингових компаній.

Виділення невирішених раніше частин загальної проблеми. Незважаючи на наявність доволі значної кількості публікацій, присвячених проблемам лізингового бізнесу, на сьогодні фрактично немає досліджень на основі використання сучасного інструментарію оцінювання ефрективності фрункціонування лізингових компаній та економетричних моделей для визначення фракторів, які найбільш суттєво впливають на діяльність таких компаній в Україні.

Формулювання цілей статті. Метою статті $€$ побудова економетричних моделей оцінювання ефрективності фрункціонування українських лізингових компаній України для визначення чинників, які справляють статистично значущий вплив на їх діяльність.

Аналіз останніх досліджень і публікацій. Щоб залишатися прибутковою в умовах жорсткої конкуренції, лізингова компанія повинна пропонувати хорошу ціну на предмет лізингу. Щоб визначити оптимальну ціну, необхідно вміти передбачити майбутні ринкові ціни та коректно ідентифрікувати чинники, які впливають на рентабельність та ефективність фоункціонування лізингових компаній. Цим проблемам присвячено чимало публікацій. Так, Ф. Мохсенідоуст та 3. Аміні Сабег у статті [1] проаналізовали роль маркетингу у підвищенні ефрективності роботи постачальників послуг лізингової компанії «Гадір», оцінено вплив таких чинників як ціна, місце, просування, фрізичні фрактори, людські ресурси, процеси та продуктивність на покращення ринкових показників компанії та ефективність функціонування компанії. За результатами цього дослідження було визначено, що найбільший вплив на ефрективність лізингової компанії «Гадір» мають ціна і тип товару.

У дослідженні [3] вивчалися фрактори, що визначають фрінансові показники фрінансових компаній Пакистану на фондовій біржі Карачі з 2008 до 2012 року. Аналіз показав, що визначальними чинниками фінансового сектору, $€$ левередж, ліквідність, розмір активів, ризик, які істотно впливають на показники діяльності фрінансових компаній. У статті рекомендується розглядати економічну додану вартість EVA (economic value added) як важливий фрактор, який визначає ефективність фрінансових операцій. На основі результатів цього дослідження та загальної ситуації на фрондовому ринку, до визначальних фракторів фрінансового сектора було віднесено кредитне плече, ліквідність, ризик та розмір компаній, які спричиняли значний вплив на EVA. Було наголошено, що більше уваги слід приділяти кредитному плечу, ліквідності та ризику. Фінансові компанії з максимальним кредитним плечем можуть із великою ймовірністю зіткнутись із фрінансовими крахом у разі невиплати боргів.

У дослідженні [4] П. Васрули та ін. було показано, що лізинг як метод фрінансування збільшує додану вартість, оскільки існує позитивна кореляція між лізингом та фрінансовими показниками діяльності лізингодавців. Стаття Н. Місу, М. Мадалено та В. Іліє [5] спрямована на вивчення того, як фрінансові змінні та екзогенні кризи впливають на фрінансові показники компаній і як ці срактори можуть допомогти менеджерам у прийнятті рішень, спрямованих на збільшення добробуту їх фрірм. Динамічні взаємодії між змінними вивчалися за допомогою панельної векторної авторегресійної моделі з використанням річних даних для 
вибірки фрірм із європейських країн. Було показано, що ліквідність, левередж і продуктивність позитивно впливають на ефективність фрункціонування фрірми, тоді як платоспроможність і оборотність активів $є$ позитивними і статистично значимими лише у випадку рентабельності власного капіталу у ролі результуючого показника. Зростання продуктивності праці призводить до того, що фрірми, як правило, докладають більше зусиль на збереження необхідного рівня фрінансових показників в умовах кризи, це при тому, що криза негативно впливає на рентабельність активів.

О. Калівошко в статті [6] відзначає, що незважаючи на здійснювані кроки щодо популяризації та підтримки лізингу з боку уряду, існують серйозні юридичні, інституційні, соціальні та економічні чинники, які сповільнюють ефективний розвиток лізингових компаній. Підхід до використання інструментарію стрестестування для визначення зовнішніх та внутрішніх для фрінансових компаній фракторів, які суттєво впливають їх рентабельність було запропоновано у роботах $[7 ; 8]$.

Виклад основного матеріалу дослідження. У подальшому нами було викорис- тано результати оцінки ефективності фрункціонування лізингових компаній на основі використання DEA аналізу. Для визначення чинників, які спричиняють статистично значущий вплив на показники їх ефрективності, отримані на основі DEA аналізу, скористаємось відповідними регресійними моделями для панельних даних. Статистичною базою слугуватимуть дані про значення запропонованих середніх мір ефективностей на основі DEA аналізу: $C R S_{\text {cep }}^{i}$ та $V R S_{\text {cep }}^{i}$ для 21 найбільших українських лізингових компаній за 2019 та 2020 роки (табл. 1).

Для побудови моделей регресії у ролі незалежних змінних нами було використано сукупні активи (ACTIV), адміністративні витрати (ADMIN), дебіторську заборгованість (DEBIT), чистий дохід від реалізації продукції (DOHID), інші операційні доходи (IN_DOH), інші операційні витрати (IN_VITR), коесріцієнт поточної ліквідності (LIKV), чистий прибуток (NET_PR), основні засоби (OSN_ZAS), собівартість реалізованої продукції (SOBIV) за 2019 та 2020 роки.

Реалізацію усіх статистичних тестів та побудова регресійних моделей проводились 3

Середні значення CRS та VRS ефективностей

Таблиця 1

\begin{tabular}{|c|c|c|c|c|}
\hline & \multicolumn{2}{|c|}{$C R S_{c e p}^{i}$} & \multicolumn{2}{|c|}{$V R S_{c e p}^{i}$} \\
\hline & 2019 & 2020 & 2019 & 2020 \\
\hline ТОВ «ОТП-лізинг» & 0,80 & 0,80 & 0,97 & 0,96 \\
\hline ТОВ «Сканія Кредіт Україна» & 0,24 & 0,78 & 0,30 & 0,91 \\
\hline ТОВ «УЛФ-фрінанс» & 0,26 & 0,15 & 0,40 & 0,27 \\
\hline ПII «ВІП-РЕНТ» & 0,30 & 0,10 & 0,75 & 0,49 \\
\hline ТОВ «Катерпіллар фрайненшл Україна» & 0,29 & 0,47 & 0,38 & 0,63 \\
\hline ТОВ «Альфра-лізинг Україна» & 0,85 & 0,38 & 0,95 & 0,79 \\
\hline TOB «Ілта» & 0,12 & 0,07 & 0,35 & 0,30 \\
\hline ТОВ «Адванс-лізинг» & 0,88 & 0,63 & 0,93 & 0,75 \\
\hline ТОВ «Бестлізинг» & 0,24 & 0,26 & 0,42 & 0,45 \\
\hline ТОВ «Віннер Лізинг» & 0,39 & 0,42 & 0,43 & 0,63 \\
\hline ТОВ «Еска капітал» & 0,71 & 0,76 & 0,80 & 0,91 \\
\hline ТОВ «Райфрфайзен Лізинг Аваль» & 1,00 & 0,72 & 1,00 & 0,85 \\
\hline ТОВ «Теком-лізинг» & 0,36 & 0,26 & 0,26 & 0,43 \\
\hline TOВ «Ексімлізинг» & 0,48 & 0,71 & 0,60 & 0,93 \\
\hline ТОВ «Лізингова компанія «Універсальна» & 0,47 & 0,69 & 0,54 & 0,92 \\
\hline ТОВ «Калина автолізинг» & 0,64 & 0,56 & 0,83 & 0,68 \\
\hline ТОВ «Рада інвест» & 0,14 & 0,90 & 0,19 & 0,91 \\
\hline ТОВ «Фастфрінанс» & 0,93 & 0,78 & 0,98 & 0,80 \\
\hline TOВ «Гектар лізинг» & 0,91 & 0,43 & 1,00 & 0,63 \\
\hline TOВ «3ЕТ-фрінанс» & 0,27 & 0,10 & 0,34 & 0,31 \\
\hline TOВ «Абіс лізинг» & 0,61 & 0,67 & 0,83 & 0,75 \\
\hline
\end{tabular}


допомогою пакету Eviews 10. Для визначення найбільш коректної для оцінювання коефріцієнтів регресії панельних даних обчислювальної техніки: FEM (fixed effects model) чи REM (random effects model), нами було використано тест Гаузмана, який підтвердив, що використання моделей панельних даних 3 фріксованими есректами FEM (fixed effects model) дає змогу отримати більш точніші апроксимації значень ефективностей на основі DEA методології (табл. 2). Регресійні моделі на основі пулу показали дуже малий коесріцієнт детермінації, що зробило недоцільним подальше їх використання.

\section{Результати тест Гаузмана}

Таблиця 2

\begin{tabular}{|c|c|c|}
\hline Змінні & CRS & VRS \\
\hline Hausman test (Chi-square) & 12,9556 & 8,4557 \\
\hline \multicolumn{3}{|c|}{ Джерело: обчислено автором }
\end{tabular}

Для підбору змінних регресійної моделі нами було використано кроковий регресійний метод, при якому фрактори по черзі включались в модель доти, поки вона не стане задовільною. Порядок включення визначався за допомогою коефріцієнту кореляції між фракторами як міри важливості фракторів, які ще не було включено в модель. Алгоритм такий: обирається фрактор, що має найбільший коефріцієнт кореляції із залежною змінною, будується регресійна модель з однією незалежною змінною. Після цього перевіряється, чи буде значущим F-критерій. Якщо він виявлявся не значущим, тоді змінну не включалось у модель. В іншому випадку включався наступний за значущістю фрактор і т.д.

У результаті підбору незалежних змінних для регресійних моделей оцінювання ефективності було побудовано кілька моделей, які перевірялись на гетероскедастичність 3 допомогою тесту Вайта, автокореляцію на основі критерію Дарбіна-Уотсона та нормальність залишків з допомогою інструментарію Eviews. Перевірка на наявність мультиколінеарності в отриманих регресійних моделях проводилась з допомогою пакету Eviews 10. Для цього було використано дисперсійно-інорляційний фрактор VIF (Variance Inflationary Factor), значення якого не перевищувало 4 для усіх змінних, що говорить про відсутність мультиколінеарності в побудованих моделях.

Для оцінки значень $C R S_{\text {cep }}^{i}$ ефективності було отримано регресійну модель, у якій пояснювальними змінними було відібрано собівартість реалізованої продукції та чистий прибуток. Результати оцінки параметрів CRS моделі подано у таблиці 3.

Таким чином, регресійна модель оцінювання $C R S_{\text {cep }}$ матиме наступний вигляд:

$C R S_{\text {cep }}=0.623513-(7.00 \mathrm{E}-07) \cdot \mathrm{SOBIV}+(3.27 \mathrm{E}-06) \cdot \mathrm{NET} \_\mathrm{PR}$ (1)

\section{Параметри рівняння регресії оцінки CRS}

\begin{tabular}{|c|c|c|c|c|}
\hline \multicolumn{5}{|c|}{ Dependent Variable: CRS } \\
\hline \multicolumn{5}{|c|}{ Method: Panel Least Squares } \\
\hline \multicolumn{5}{|l|}{ Sample: 2019-2020 } \\
\hline \multicolumn{5}{|l|}{ Periods included: 2} \\
\hline \multicolumn{5}{|c|}{ Cross-sections included: 21} \\
\hline \multicolumn{5}{|c|}{ Total panel (balanced) observations: 42} \\
\hline Variable & Coefficient & Std. Error & t-Statistic & Prob. \\
\hline C & 0.623513 & 0.054654 & 11.40839 & 0.0000 \\
\hline SOBIV & $-7.00 \mathrm{E}-07$ & 2.95E-07 & -2.371974 & 0.0278 \\
\hline NET_PR & 3.27E-06 & 1.17E-06 & 2.794925 & 0.0112 \\
\hline \multicolumn{5}{|l|}{ Effects Specification } \\
\hline \multicolumn{5}{|c|}{ Cross-section fixed (dummy variables) } \\
\hline R-squared & 0.831986 & Mean dependent var & 0.512619 & \\
\hline Adjusted R-squared & 0.753072 & S.D. dependent var & 0.274413 & \\
\hline S.E. of regression & 0.183453 & Akaike info criterion & -0.248037 & \\
\hline Sum squared resid & 0.673099 & Schwarz criterion & 0.662171 & \\
\hline Log likelihood & 27.20878 & Hannan-Quinn criter. & 0.085590 & \\
\hline F-statistic & 3.416062 & Durbin-Watson stat & 3.818182 & \\
\hline Prob (F-statistic) & 0.003999 & & & \\
\hline
\end{tabular}


Параметри рівняння регресії оцінки VRS (модель 2)

Таблиця 4

\begin{tabular}{|c|c|c|c|c|}
\hline \multicolumn{5}{|c|}{ Dependent Variable: VRS } \\
\hline \multicolumn{5}{|c|}{ Method: Panel Least Squares } \\
\hline \multicolumn{5}{|l|}{ Sample: 20192020} \\
\hline \multicolumn{5}{|l|}{ Periods included: 2} \\
\hline \multicolumn{5}{|c|}{ Cross-sections included: 21} \\
\hline \multicolumn{5}{|c|}{ Total panel (unbalanced) observations: 42} \\
\hline Variable & Coefficient & Std. Error & t-Statistic & Prob. \\
\hline C & 0.194059 & 0.278598 & 0.696554 & 0.4983 \\
\hline ADMIN & 4.49E-06 & $2.31 \mathrm{E}-06$ & 1.946003 & 0.0674 \\
\hline OSN_ZAS & 4.82E-06 & 1.94E-06 & 2.486320 & 0.0261 \\
\hline SOBIV & $-1.13 E-06$ & $4.21 \mathrm{E}-07$ & -2.691150 & 0.0176 \\
\hline \multicolumn{5}{|c|}{ Effects Specification } \\
\hline \multicolumn{5}{|c|}{ Cross-section fixed (dummy variables) } \\
\hline R-squared & 0.895920 & Mean dependent var & 0.654242 & \\
\hline Adjusted R-squared & 0.743802 & S.D. dependent var & 0.246628 & \\
\hline S.E. of regression & 0.124833 & Akaike info criterion & -1.043115 & \\
\hline Sum squared resid & 0.202583 & Schwarz criterion & -0.136141 & \\
\hline Log likelihood & 37.21140 & Hannan-Quinn criter. & -0.737946 & \\
\hline F-statistic & 5.889649 & Durbin-Watson stat & 3.882353 & \\
\hline Prob (F-statistic) & 0.001082 & & & \\
\hline
\end{tabular}

Джерело: обчислено автором

Модель 1 оцінки CRS має досить високий рівень адекватності, оскільки частина варіації залежної змінної, яка пояснюється самою моделлю становить 0,83. Iз CRS моделі випливає, що збільшення собівартості реалізованої продукції призводить до зменшення ефрективності фрункціонування таких компаній при припущенні про наявність сталого есректу масштабу. Цілком природньо, що зростання чистого прибутку сприяє покращенню середнього рівня технічної ефективності у лізинговому бізнесі.

Для оцінювання середнього значення VRS українських лізингових компаній, було отримано регресійну модель 2 із значенням коефіцієнта детермінації 0,89. Легко бачити, що при прийнятті припущення про наявність змінного ефректу масштабу на значення технічної ефективності значний вплив матиме розмір компанії. Так, у цьому випадку зростання загального обсягу адміністративних витрат та розміру основних засобів, що значною мірою характеризує масштаб діяльності компаній, сприяють зростанню ефективності їх фрункціонування. Аналогічно, як і у випадку CRS моделей, зростання собівартості реалізованої продукції негативно впливає на ефективність фрункціонування лізингових компаній.

Регресійну модель оцінювання $V R S_{\text {cep }}$ на основі панельних даних можна буде представити наступним чином:
$V R S_{\text {cep }}=0.194059+(4.49 \mathrm{E}-06) \cdot \mathrm{ADMIN}+(4.82 \mathrm{E}-06) \cdot$ OSN_ZAS(1.13E-06) SOBIV

Аналіз показав, що такі змінні як сукупні активи (ACTIV), дебіторська заборгованість (DEBIT), чистий дохід від реалізації продукції (DOHID), інші операційні доходи (IN_DOH), коефіцієнт поточної ліквідності (LIKV) виявились статистично незначущими для побудованих регресійних моделей оцінювання значень запропонованих авторами нових показників ефрективності фрункціонування лізингових компаній України $C R S_{\text {cep }}^{i}$, $V R S_{c e p}^{i}$ та $S E_{c e p}^{i}$, отриманих як середні значення відповідних ефективностей і-ї компанії.

Висновки. Отримані у роботі регресійні моделі дають змогу визначити набори як зовнішніх, так і внутрішніх чинників, які спричиняють найбільш суттєвий вплив на ефективність фуннціонування лізингових компаній. Ефективність на основі VRS припущення або ВСС моделі, яка дає змогу враховувати зміну ефрективності при зміні масштабу операцій, найбільш чутлива до змін адміністративних витрат, розміру основних засобів та собівартості реалізованої продукції. Ефрективність на основі CRS припущення або CCR моделі, яка передбачає пропорційне зростання вхідних та вихідних показників діяльності компаній, виявилась найбільш чутливою до зміни 
чистого прибутку та собівартості реалізованої продукції. Таким чином, найчастіше в регресійних моделях оцінювання ефективності функціонування лізингових компаній у ролі пояснювальних змінних виступають собівартість реалізованої продукції та чистий прибу- ток. Іншими словами, згідно із побудованими регресійними моделями, ефективність діяльності лізингодавця у більшості випадків залежить від вартості майна, що передано ним у орінансову оренду та чистого прибутку таких компаній.

\section{СПИСОК ВИКОРИСТАНИХ ДЖЕРЕЛ:}

1. Mohsenidoust Fatemeh, Amini Sabegh Zeinolabedin. Studying the role of marketing mix on performance of leasing service providers firms (case: Ghadir leasing company). Маркетинг і менеджмент інновацій. 2016. № 2. C. 215-221.

2. Bina Era Dani, Gunarto, Mahmutarom. Factors affecting deviations in leasing practices towards the principles of agreement law. International Journal of Business, Economics and Law. 2017. Vol. 14. Issue 5. P. 161-168.

3. Khan, Muhammad Kamran and Nouman, Mohammad and Imran, Muhammad. Determinants of financial performance of financial sectors (An assessment through economic value added). MPRA Paper. 2015. No. 81281. P. 1-32.

4. Wafula Peter Sindani, Namusonge Gregory S., Elizabeth Nambuswa. Effect of Leasing on the Financial Performance of the County Government of Trans Nzoia. International Journal of Scientific and Research Publications. September 2016. Volume 6. Issue 9. P. 624-631.

5. Bărbuță-Mișu N., Madaleno M., llie V. Analysis of Risk Factors Affecting Firms' Financial Performance Support for Managerial Decision-Making. Sustainability. 2019. № 11(18). 19 p.

6. Калівошко О.М. Оцінка сучасного стану лізингових компаній як інституту інфраструктури фрінансовокредитного ринку. Економіка та держава. 2019. № 4. С. 63-68.

7. Кишакевич Б.Ю. Стрес-тестування економічного капіталу банку на основі однофракторних моделей. Науковий вісник НЛту України. 2011. Вип. 21-02. С. 210-219.

8. Кишакевич Б.Ю. Стрес-тестування кредитного портфеля банку на основі багатофракторних моделей. Економічний простір. 2011. № 45. С. 161-170.

\section{REFERENCES:}

1. Mohsenidoust F., Amini Zeinolabedin (2016) Studying the role of marketing mix on performance of leasing service providers firms (case:Ghadir leasing company). Marketinh i management innovacij [Marketing and innovation management], 2, 215-221. (in Ukrainian)

2. Bina Era Dani, Gunarto, Mahmutarom (2017) Factors affecting deviations in leasing practices towards the principles of agreement law. International Journal of Business, Economics and Law, vol. 14, iss. 5, 161-168.

3. Khan, Muhammad Kamran and Nouman, Mohammad and Imran, Muhammad (2015) Determinants of financial performance of financial sectors (An assessment through economic value added), MPRA Paper, no. 81281, 1-32.

4. Wafula Peter Sindani, Namusonge Gregory S., Elizabeth Nambuswa (2016) Effect of Leasing on the Financial Performance of the County Government of Trans Nzoia. International Journal of Scientific and Research Publications, vol. 6, iss. 9, 624-631.

5. Bărbuță-Mișu N, Madaleno M, llie V. (2019) Analysis of Risk Factors Affecting Firms' Financial Performance Support for Managerial Decision-Making. Sustainability, 11(18), $19 \mathrm{p}$.

6. Kalivoshko, O. (2019) Evaluation of the modern condition of leasing companies as a institute of the infrastructure of the financial and credit market, Ekonomika ta derzhava, 4, 63-68.

7. Kyshakevych B.Y. (2011) Stres-testuvannia ekonomichnoho kapitalu banku na osnovi odnofaktornykh modelei [Stress testing of the bank's economic capital based on one-factor models]. Naukovyi visnyk NLTU Ukrainy, 21-02, 210-219.

8. Kyshakevych B.Y. (2011) Stres-testuvannia kredytnoho portfelia banku na osnovi bahatofaktornykh modelei [Stress testing of the bank's loan portfolio based on multifactor models]. Ekonomichnyi prostir, 45, 161-170. 